\section{Natural zeolite as a replacement for resin in the cation exchange process of cesium on post-irradiated nuclear fuel}

\author{
Aslina Br. Ginting $\complement^{\circledR}$, \\ Amini Siti, \\ Noviarty, \\ Yanlinastuti, \\ Arif Nugroho, \\ Boybul
}

\begin{abstract}
Characterization of natural salts from Bayah, Lampung, and Tasikmalaya, Indonesia has been carried out as a substitute for synthetic resins. The characteristics include zeolite activation with $\mathrm{NH}_{4} \mathrm{Cl}$, and heated at $200^{\circ} \mathrm{C}$, the bond stability test of ${ }^{137} \mathrm{Cs}$-zeolite, chemical composition analysis, surface area, pore size, analysis of Cs cation exchange capacity (CEC), diffusion coefficient $\left(D_{i}\right)$, activation energy $\left(E_{a}\right)$, and absorption of three zeolites. To do this, pipette $50 \mu \mathrm{l}$ of a standard solution of ${ }^{137} \mathrm{Cs}$ from the National Institute of Standards and Technology (NIST), put in, $2 \mathrm{ml}$ of $0.1 \mathrm{~N} \mathrm{HCl}$, and then add $1 \mathrm{~g}$ of zeolite and stir each for 1, 2, 3, 4, 5, and $24 \mathrm{~h}$. Based on this stirring time, the ${ }^{137} \mathrm{C}$ isotope will exchange ions with $\mathrm{NH}_{4}$-zeolite to ${ }^{137} \mathrm{Cs}$-zeolite in the solid phase. The content of ${ }^{137} \mathrm{Cs}$ in ${ }^{137} \mathrm{Cs}$-zeolites (solid phase) was analysed using a gamma spectrometer. The results of the chemical composition analysis showed that the character of zeolite from Lampung has a Si/Al ratio, with a CEC value of $1.448 \mathrm{mEq} / \mathrm{g}$ which is greater than Bayah and Tasikmalaya, while the $D_{i}$ and $E_{a}$ values for the three select types were obtained almost the same. Moreover, the stability test of the Cs ion bond with zeolite showed no significant release of Cs ions from the zeolite structure. It can be concluded that the three soloists tested that the zeolite from Lampung has better characters. The results of ${ }^{137} \mathrm{Cs}$ isotope separation in $150 \mu \mathrm{l}$ of $\mathrm{U}_{3} \mathrm{Si}_{2} / \mathrm{Al}$ fuel solution post-irradiation using zeolite from Lampung and Dowex resins obtained almost the same recovery around 98-99\%, so it can be concluded that zeolite from Lampung can be used as a substitute for synthetic resin in the cation exchange process for the ${ }^{137} \mathrm{Cs}$ isotope in nuclear fuel post-irradiated.
\end{abstract}

Keywords: Zeolites $\bullet$ Resin $\bullet$ Cation exchange $\bullet$ Cesium $\bullet$ Nuclear fuel

A. Br. Ginting ${ }^{\bowtie}$, A. Siti, Noviarty, Yanlinastuti,

A. Nugroho, Boybul

Center for Nuclear Fuel Technology

National Nuclear Energy Agency of Indonesia

Buid. 20, Kawasan Puspiptek-Setu

Tangerang Selatan 15314, Indonesia

E-mail: aslinaboruginting@gmail.com

Received: 4 May 2020

Accepted: 2 October 2020

\section{Introduction}

The nuclear fuels $\mathrm{U}_{3} \mathrm{O}_{8} / \mathrm{Al}$ or $\mathrm{U}_{3} \mathrm{Si}_{2} / \mathrm{Al}$, used in the multipurpose reactor G.A. Siwabessy (RSG-GAS) at Serpong, Indonesia, contain $19.75 \%$ enriched ${ }^{235} \mathrm{U}$. At the reactor, the fission reaction occurred between ${ }^{235} \mathrm{U}$ with neutron. The fission reaction produced products including such as ${ }^{144} \mathrm{Ba},{ }^{137} \mathrm{Cs}$, ${ }^{90} \mathrm{Sr}$, and ${ }^{89} \mathrm{Kr}$ and heavy elements such as uranium and transuranium. The nuclear fuel of post-irradiation contains more ${ }^{137} \mathrm{Cs}$ than other isotopes because the former has $6.26 \%$ fission yields [1]. Fission yields of isotopes are very important to determine the content or quantity of isotopes in post-irradiated fuel and are one of the considerations in the selection of isotopes to determine burn-up. In addition to having high fission yields, ${ }^{137} \mathrm{Cs}$ isotopes are transmitters of gamma radiation and have a long half-life $\left(t_{1 / 2}=\right.$ 30.17 years); therefore, they are stable as an isotope to monitor burn-up. Several isotopes can be used for calculations of burn-up, such as ${ }^{137} \mathrm{Cs},{ }^{235} \mathrm{U}$, and ${ }^{239} \mathrm{Pu}$. Determining the isotope composition of ${ }^{137} \mathrm{Cs}$, ${ }^{235} \mathrm{U}$, and ${ }^{239} \mathrm{Pu}$ as both $\alpha$ and $\gamma$ radiation transmitters can be calculated using physicochemical separa-

0029-5922 @ 2021 The Author(s). Published by the Institute of Nuclear Chemistry and Technology.

This is an open access article under the CC BY-NC-ND 4.0 licence (http://creativecommons.org/licences/by-nc-nd/4.0/). 
tion through cation-anion exchange methods and spectrometer- $\alpha / \gamma$ analysis. In this study, the separation of ${ }^{137} \mathrm{Cs}$ from ${ }^{235} \mathrm{U}$ and other isotopes was carried out using the cation exchange method, while ${ }^{235} \mathrm{U}$ was separated from ${ }^{239} \mathrm{Pu}$ using an anion exchange method with Dowex resin [1]. The separation of ${ }^{137} \mathrm{Cs}$ contained in nuclear fuel of post-irradiation is usually performed using synthetic resin. The price of synthetic resin is very expensive, so, in this study, the separation of ${ }^{137} \mathrm{Cs}$ is performed using several types of natural zeolite. Thus, this study focuses on the effect that the character of natural zeolite has on the kinetics of the diffusion of Cs ions. The results of this study are expected to allow natural zeolite to replace resin in the separation of ${ }^{137} \mathrm{Cs}$ in post-irradiated nuclear fuel.

\section{Theory of the cation exchange method using zeolites}

\section{Formula and framework of the structure of zeolite}

Zeolites are hydrated aluminosilicate crystals containing alkali or alkaline earth cations in a three-dimensional framework. The basic framework of the zeolite structure consists of tetrahedral units of $\mathrm{AlO}_{2}$ and $\mathrm{SiO}_{2}$ interconnected with $\mathrm{O}$ atoms; therefore, zeolite has the empirical formula $\mathrm{M}^{n+}\left[\left(\mathrm{AlO}_{2}\right)_{x}\left(\mathrm{SiO}_{2}\right)_{y}\right] \cdot z \mathrm{H}_{2} \mathrm{O}$ [2]. The M notation was the alkali or alkaline earth metal cations, where the particular numbers were $x, y$, and $z$ as $n$ was the change of the metal ions. From the above formula, zeolite can be seen the existence of the three components, such as frame $\left[\left(\mathrm{AlO}_{2}\right)_{x}\left(\mathrm{SiO}_{2}\right)_{y}\right]$, alkali metal $\mathrm{M}^{n+}\left({ }^{144} \mathrm{Ba},{ }^{137} \mathrm{Cs}\right.$, and $\left.{ }^{90} \mathrm{Sr}\right)$, and $\mathrm{H}_{2} \mathrm{O}$ [2], which is part of zeolite. Zeolite structures consist of four $\mathrm{O}$ atoms that are interconnected with all $\mathrm{Al}$ atoms to form a tetrahedron. $\mathrm{Si}^{4+}$ atoms are replaced by $\mathrm{Al}^{3+}$ so that the zeolite is negatively charged and will be neutralized by alkali or alkaline earth cations, such as $\mathrm{NH}_{4}^{+}, \mathrm{Na}^{+}, \mathrm{K}^{+}, \mathrm{Mg}^{2+}$, and $\mathrm{Ca}^{2+}$, in the cavity of the zeolite structure, thus producing a stable compound [3]. Therefore, zeolite is likely to be a good substitute for the resin in the ion exchange process. Zeolite structures are porous and contain water molecules that are easily separted from the rest of the structure by the heating process. This phenomenon means that zeolite can be used as a specific adsorbent in molecular sieves, ion exchangers, and as a catalyst. The unique characteristics of zeolite cause it to be used widely in various industries $[4,5]$.

\section{The cation exchange capacity of zeolite}

The cation exchange capacity (CEC) of zeolites is the maximum number of $\mathrm{Cs}$ ion in milli-equivalent (mEq) that can be absorbed by $1 \mathrm{~g}$ of zeolite under equilibrium conditions, as given in Eq. (1) [6]

$$
\mathrm{CEC}=\frac{\mathrm{Cs}_{0}-\mathrm{Cs}_{i}}{\text { Mass Zeo }}
$$

where CEC is the cation exchange capacity of the zeolite $(\mathrm{mEq} / \mathrm{g}) ; \mathrm{Cs}_{0}$ is the mole equivalent weight of Cs before the cation exchange process; $\mathrm{Cs}_{1}$ is the mole equivalent weight of Cs, after the cation exchange process; and Mass Zeo is the weight of zeolite used for the cation exchange process (g).

The CEC of natural zeolite varies from $1.5 \mathrm{mEq} / \mathrm{g}$ to $6 \mathrm{mEq} / \mathrm{g}$ and is dependent upon the amount of $\mathrm{Al}^{+}$ and $\mathrm{Si}^{+}$atoms in the structure of the zeolite. Zeolites have a higher CEC than clay rocks such as kaolin $(0.03-015 \mathrm{mEq} / \mathrm{g})$, bentonite $(0.80-1.50 \mathrm{mEq} / \mathrm{g})$, and vermiculite $(1-1.50 \mathrm{mEq} / \mathrm{g})[7,8]$.

Most zeolite has a chemical composition consisting of $\mathrm{SiO}_{2}, \mathrm{Al}_{2} \mathrm{O}_{3}, \mathrm{Fe}_{2} \mathrm{O}_{3}, \mathrm{~K}_{2} \mathrm{O}, \mathrm{TiO}_{2}, \mathrm{MgO}, \mathrm{CaO}$, and $\mathrm{Na}_{2} \mathrm{O}$. Zeolites have a variety of structures, with specific characteristics and depending on how they were formed [9]. Zeolite is a very common mineral in Indonesia, particularly in Bayah, Lampung, and Tasikmalaya; it is also present in Java and Sumatra, where it is generally composed of clinoptilolite and mordenite in varying proportions, depending on its source.

The results of the composition analysis of zeolites from Bayah, Lampung, and Tasikmalaya using X-ray diffractometer (XRD)-Panalytical product with cobalt sources showed that $74 \%$ of the three types of zeolites were clinoptilolite with mordenite, while others were quartz, clay and gips, as shown in Fig. 1 [10, 11].

$\mathrm{a}$

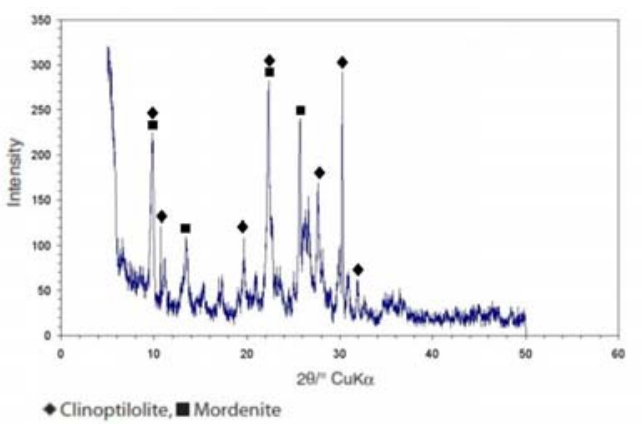

$\mathrm{b}$

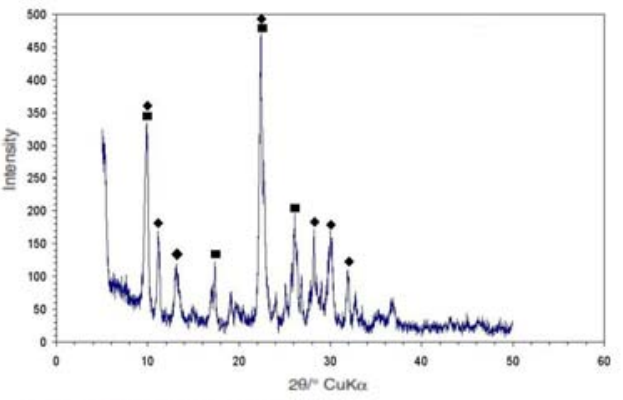

- Clinoptilolite, Mordenite

c

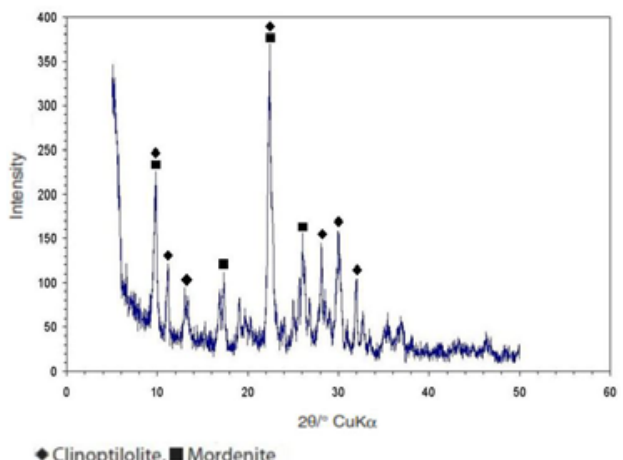

Fig. 1. XRD peak pattern of the natural zeolite dried at $200^{\circ} \mathrm{C}$ : (a) Bayah, (b) Lampung, and (c) Tasikmalaya. 
Various types of zeolite have different absorption capacities for different molecules. The selectivity of each type of zeolite depends on its structure. Therefore, zeolite can be used as filters for ions or molecules and can also be used as ion exchange materials in chemical analysis as a substitute for synthetic resin as a catalyst in chemical processes. These materials are important because ion exchanges occur in a solution containing anions, cations, and water molecules, and one or more of these ions must be absorbed by the solid-phase microporous matrix. Water molecules contained in the matrix ion will cause ionic equilibrium and neutralize the solution. Ions in the solution can also move freely within the microporous matrix; this phenomenon caused by zeolite composed of alkali or alkaline earth cations with the empirical formula $\mathrm{M}^{n+}\left[\left(\mathrm{AlO}_{2}\right)_{x}\left(\mathrm{SiO}_{2}\right)_{y}\right] \cdot z \mathrm{H}_{2} \mathrm{O} . \mathrm{M}^{n+}$ is a cation source that can move freely and can be exchanged, in part or completely, with other cations [12-14].

\section{Selectivity of zeolites for cesium cation exchange}

Zeolites are generally composed of mordenite and clinoptilolite in varying proportions. Mordenite acts as an adsorbent or ion exchange and is highly selective toward Cs ions. Cation exchange occurs selectively in the order $\mathrm{Cs}>\mathrm{Sr}=\mathrm{Ba}>\mathrm{U}$, while the selective cation exchange of clinoptilolite ions occurs in the order Cs $>$ $\mathrm{Sr}>\mathrm{Ba}>\mathrm{U}[13]$. Previous studies tested the selectivity of zeolite cation exchanges with fission products in nuclear fuel of post-irradiation, especially for the $\mathrm{Cs}, \mathrm{Sr}$, and $\mathrm{U}$ isotopes. The results of the test showed that zeolites were very selective for the separation of Cs $>\mathrm{Sr}>\mathrm{U}$ isotopes $[13,14]$. Properties of zeolite, such as the size of its cations and hydrated cations, surface area, ion radius, and chemical composition, affect the process of cation exchange between zeolite with the isotope of fission products. When the surface area and ion radius differ, the cations cannot be exchanged completely. A phenomenon that occurs in the process of cation exchange was used to separate ${ }^{137} \mathrm{Cs}$ from the other fission products in the post-irradiation nuclear fuel [15].

In addition to the properties of the zeolite that affect the ion exchange and absorption processes, other important properties of zeolite are its CEC and the diffusion of ions [16]. The processes of ion exchange and absorption by zeolite follow the kinetics of ion diffusion mechanisms. This phenomenon occurs because different types of natural zeolites consist of various different minerals. Ion diffusion processes on the structure of zeolite can control the ion exchange and absorption processes. The CEC values can be used to determine the effectiveness of ion exchange and absorption processes. The ion exchange capacity of zeolite particles is usually expressed as diffusion coefficients $\left(D_{i}\right)$. The $D_{i}$ can be determined using Eq. (2); the value of the diffusion coefficient $\left(D_{i}\right)$ is then used to determine the kinetics parameters, such as activation energy $\left(E_{a}\right)$, using the Arrhenius formula shown in Eq. (3) [17].

$$
F_{t} / F_{\sim}=6 / r \sqrt{D_{i}} \cdot t / \pi
$$

where $F_{t}$ is fraction values of ions exchanged at time $t ; F_{\sim}$ is the fraction of ions exchanged in $24 \mathrm{~h} ; r$ is the ion radius of zeolite particles; $D_{i}$ is the diffusion coefficient $\left(\mathrm{m}^{2} / \mathrm{s}\right) ; t$ is the contact time $(\mathrm{s}) ; \pi-22 / 7$.

$$
D_{i}=D_{0} \exp \left(-E_{a} / \mathrm{RT}\right)
$$

where $D_{i}$ is the diffusion coefficient at temperature $\mathrm{T}_{i}$ $\left(\mathrm{m}^{2} / \mathrm{s}\right) ; D_{0}$ is the diffusion coefficient at temperature $\mathrm{T}_{0}\left(\mathrm{~m}^{2} / \mathrm{s}\right) ; E_{a}$ is the activation energy $(\mathrm{J} / \mathrm{mole}) ; \mathrm{R}$ is Boltzmann constant $\left(1.36 \times 10^{-23} \mathrm{~J} / \mathrm{K}\right)$; $\mathrm{T}$ is the temperature $(\mathrm{K})$.

The magnitude of the $E_{a}$ is obtained from the value of the slope, as obtained from the equation of linearity between the $D_{i}$ and temperature $(\mathrm{T})$. The amount of $E_{a}$ is the energy needed for Cs ions to be absorbed onto zeolites. If the value of $E_{a}$ is low, Cs ions diffuse easily into the zeolite framework because the ion exchange process in the zeolite is not blocked by the effects of the ion sieve $[17,18]$.

This study aimed to determine the properties of natural zeolites from the Bayah, Lampung, and Tasikmalaya regions (particle diameter $-270+400$ mesh) and determine their effects on the kinetics of the diffusion process and CEC of ion Cs. These properties will determine whether the character of natural zeolite can be used as a substitute for synthetic resins in cation exchange during the separation of ${ }^{137} \mathrm{Cs}$ isotope from uranium in nuclear fuel of $\mathrm{U}_{3} \mathrm{Si}_{2} / \mathrm{Al}$ post-irradiation.

\section{Experimental section}

By mixing with an $\mathrm{NH}_{4} \mathrm{Cl}$ solution, natural zeolites from Bayah, Lampung, and Tasikmalaya each weighing $1 \mathrm{~g}$ and particle diameter $-270+400$ mesh were activated, stirred, and washed until the water ran clear of chlorides. The zeolites were then dried at $200^{\circ} \mathrm{C}$ to form $\mathrm{NH}_{4}^{+}$-zeolite powder. The chemical composition of this powder was then characterized using X-ray fluorescence (XRF) spectroscopy, type Arl-Quant'X from Thermo Scientific, and the surface area, pore radius, and zeolite adsorption were analysed using a surface area meter. $\mathrm{NH}_{4}^{+}$-zeolite heated at temperatures of up to $200^{\circ} \mathrm{C}$ was analysed for the surface area, pore radius, and adsorption capability. Three types of natural $\mathrm{NH}_{4}^{+}$-zeolite powders were used as cation exchange materials for the ${ }^{137} \mathrm{Cs}$ isotope of standard CRM 4233E from the National Institute of Standard Technology (NIST). The standard of ${ }^{137} \mathrm{Cs}$ solution with a volume of $50 \mathrm{ml}$ in $2 \mathrm{ml} 0.1 \mathrm{~N} \mathrm{HCl}$ was added to the vial (Triplo) and $1 \mathrm{~g}$ of $\mathrm{NH}_{4}^{+}$-zeolite powder (zeolites from Bayah, Lampung, and Tasikmalaya) was added. The solution was stirred for $1,2,3,4,5$, and $24 \mathrm{~h}$ with stirring speed of $1000 \mathrm{rpm}$ and then allowed to stand for $24 \mathrm{~h}$ so that the solid phase was separated from the liquid phase. The result of the cation exchange process is that the Cs ion has been bound by zeolites in the solid phase and other ions in the liquid phase. The amount of Cs ion bound in the zeolite as ${ }^{137}$ Cs-zeolite (solid phase) with the various stirring times was determined using a gamma spectrometer 
Genie 2000 with the high purity germanium (HPGe) detector, Canberra product.

The kinetic $D_{i}$ and $E_{a}$ were calculated using Eqs. (2) and (3), while the CEC of the Cs ions was determined effectively by stirring for $1 \mathrm{~h}$ (the optimal result in the variable in stirring times) and analysed using Eq. (1). The stability of the solid ${ }^{137}$ Cs-zeolite bond was tested by heat treatments at temperatures of $25,200,500$, and $600^{\circ} \mathrm{C}$ with three of the samples (Triplo), after which the samples were washed and rinsed using water (leached). The effect of heat treatment was expected to reduce the desorption of ${ }^{137} \mathrm{Cs}$ from the zeolite. The content of ${ }^{137} \mathrm{Cs}$ isotope (as a gamma-ray emitter) in the leach solution was then analysed using a gamma spectrometer.

The zeolite with the best character is then used as a cation exchange material for the separation of ${ }^{137} \mathrm{Cs}$ isotope in a nuclear fuel solution of $\mathrm{U}_{3} \mathrm{Si}_{2} / \mathrm{Al}$ post-irradiation. Using a diamond cutting machine in a hot cell, the nuclear fuel of $\mathrm{U}_{3} \mathrm{Si}_{2} / \mathrm{Al}$ post-irradiation is cut to the top, middle, and bottom positions and then dissolved with $5 \mathrm{ml}$ of $\mathrm{HCl} 6 \mathrm{~N}$ and $6 \mathrm{~N} \mathrm{HNO}_{3}$ in $25 \mathrm{ml}$. At the top, middle, and bottom, each pipette has a nuclear fuel solution of up to $150 \mathrm{ml}$ and put into $2 \mathrm{ml} \mathrm{HCl} 0.1 \mathrm{~N}$. Then, $1 \mathrm{~g}$ of zeolite from Lampung was added and the cation exchange process carried out for $1 \mathrm{~h}$, so that the solid phase separated with phase liquid. The ${ }^{137} \mathrm{C}$ isotope is bound by zeolite in the solid phase and the other isotopes are in the liquid phase. The isotope content of ${ }^{137} \mathrm{Cs}$ in the solid phase is measured using a gamma spectrometer for $5000 \mathrm{~s}$. The results of the ${ }^{137} \mathrm{Cs}$ isotope separation by a cation exchange method using zeolite were then compared with the results of the separation using synthetic resin.

\section{Results and discussion}

\section{Activation of zeolite using $\mathrm{NH}_{4} \mathrm{Cl}$}

The zeolites from Bayah, Lampung, and Tasikmalaya were activated with saturated $\mathrm{NH}_{4} \mathrm{Cl}$ and used to obtain monocationic zeolite $\left(\mathrm{NH}_{4}-\mathrm{Z}\right)$, which is readily usable as a cation exchange material. After the activation process, all cations in zeolite can be replaced by ammonium cations homogeneously or as a monocation. The $\mathrm{NH}_{4}^{+}$-zeolite powder is used as a cation exchange material to absorb ${ }^{137} \mathrm{Cs}$ isotopes in standard CRM. An $\mathrm{NH}_{4}^{+}$-zeolite was obtained from the results of the activation of zeolite with $\mathrm{NH}_{4} \mathrm{Cl}$, as shown in the following reaction

(4) $\mathrm{NH}_{4} \mathrm{Cl}^{+}$-zeolite $\left(\mathrm{M}^{n+}\right) \rightarrow \mathrm{NH}_{4}^{+}$-zeolite $+\mathrm{MCl}_{n}$

where $\mathrm{M}$ is the alkali and alkaline earth metals (cations in zeolites) and $n$ is the valence electron of the metal. The cation exchange process between $\mathrm{NH}_{4}^{+}$-zeolite and ${ }^{137} \mathrm{Cs}$ isotope occurs as the following reaction.

\section{(5) $\mathrm{NH}_{4} \mathrm{Cl}^{+}$-zeolite $+{ }^{137} \mathrm{Cs} \rightarrow{ }^{137} \mathrm{Cs}$-zeolite $+\mathrm{NH}_{4}^{+}$}

The hydrated ionic radius of $\mathrm{NH}_{4}^{+}=331 \mathrm{pm}$, ${ }^{137} \mathrm{Cs}=329 \mathrm{pm}, \mathrm{U}^{4+}=80 \mathrm{pm}, \mathrm{U}^{6+}=97 \mathrm{pm}$, and $\mathrm{Sr}^{2+}$ $=412 \mathrm{pm}$ so that the $\mathrm{Cs}^{+}$ion is easier to exchange with $\mathrm{NH}_{4}^{+}$when compared with $\mathrm{Sr}^{2+}$ ion or $\mathrm{U}$ in the zeolite framework.

\section{Analysis of chemical composition}

The results of the XRF analysis of the chemical composition of zeolites from Bayah, Lampung, and Tasikmalaya showed that they contained $\mathrm{Si}, \mathrm{Al}, \mathrm{Ca}$, $\mathrm{Fe}, \mathrm{Mg}, \mathrm{Na}, \mathrm{K}$, and $\mathrm{Ti}$, as shown in Table 1 . Table 1 shows $68.07 \%$ silica and $16.52 \%$ alumina are present in zeolite from Lampung, which is greater than the quantity of these elements found in zeolite from Bayah and Tasikmalaya.

In addition, the $\mathrm{P}$ and $\mathrm{Mn}$ elements were obtained as impurities in zeolites from Lampung and Bayah, while the element $\mathrm{P}$ was not obtained as impurities in zeolites from Tasikmalaya. The zeolite used as a cation exchange material must contain $\mathrm{Si}$ and $\mathrm{Al}$ in the ratio $(\mathrm{Si} / \mathrm{Al})>1$, because $\mathrm{Si}^{4+}$ atoms are replaced by $\mathrm{Al}^{3+}$ and the unstable charge of $\mathrm{Si}^{+}$ is stabilized by ${ }^{137} \mathrm{Cs}$ isotope [16]. Each of the three zeolites can be used as a cation exchange material because they each have a $(\mathrm{Si} / \mathrm{Al})$ ratio $>1$, the most potential zeolite from Lampung.

\section{Analysis of surface area}

The results of the surface area analyses, pore size, and adsorption, which underwent heat treatment up to $200^{\circ} \mathrm{C}$, are shown in Table 2 . Table 2 shows that zeolite from Lampung had a larger surface area

Table 1. Chemical composition of zeolites from Bayah, Lampung, and Tasikmalaya

\begin{tabular}{lcccc}
\hline $\begin{array}{c}\text { Oxide } \\
\text { elements }\end{array}$ & $\begin{array}{c}\text { Zeolites from } \\
\text { Bayah }(\% \mathrm{w} / \mathrm{w})\end{array}$ & $\begin{array}{c}\text { Zeolites from } \\
\text { Lampung }(\% \mathrm{w} / \mathrm{w})\end{array}$ & $\begin{array}{c}\text { Zeolites from } \\
\text { Tasikmalaya }(\% \mathrm{w} / \mathrm{w})\end{array}$ & $\begin{array}{c}\text { Mordenite standard } \\
(\% \mathrm{w} / \mathrm{w})\end{array}$ \\
\hline $\mathrm{SiO}_{2}$ & 4.350 & 68.070 & 62.520 & 78.580 \\
$\mathrm{Al}_{2} \mathrm{O}_{3}$ & 14.20 & 16.520 & 13.760 & 17.330 \\
$\mathrm{CaO}$ & 3.720 & 2.270 & 3.130 & 0.920 \\
$\mathrm{Fe}_{2} \mathrm{O}_{3}$ & 1.720 & 1.530 & 1.650 & 0.350 \\
$\mathrm{MgO}$ & 1.630 & 0.570 & 1.470 & 0.450 \\
$\mathrm{Na}_{2} \mathrm{O}$ & 1.840 & 0.930 & 1.860 & 1.180 \\
$\mathrm{~K}_{2} \mathrm{O}$ & 2.860 & 2.280 & 2.010 & 0.860 \\
$\mathrm{P}_{2} \mathrm{O}$ & 0.052 & 0.034 & - & - \\
$\mathrm{TiO}_{2}$ & 2.154 & 0.135 & 2.170 & 0.080 \\
$\mathrm{MnO}$ & 0.022 & 0.033 & 0.032 & - \\
\hline
\end{tabular}


Table 2. Surface area, pore size and adsorption of zeolites from Bayah, Lampung, and Tasikmalaya

\begin{tabular}{lccc}
\hline $\begin{array}{c}\text { Types } \\
\text { of zeolites }\end{array}$ & $\begin{array}{c}\text { Surface area } \\
\left(\mathrm{m}^{2}\right)\end{array}$ & $\begin{array}{c}\text { Pore size } \\
(\AA)\end{array}$ & $\begin{array}{c}\text { Adsorption } \\
(\mathrm{ml} / \mathrm{g})\end{array}$ \\
\hline Bayah & 6.353 & 16.235 & 13.250 \\
Lampung & 10.048 & 16.065 & 24.500 \\
Tasikmalaya & 8.332 & 16.801 & 13.850 \\
Standard & 1.010 & 30.915 & 4.900 \\
\hline
\end{tabular}

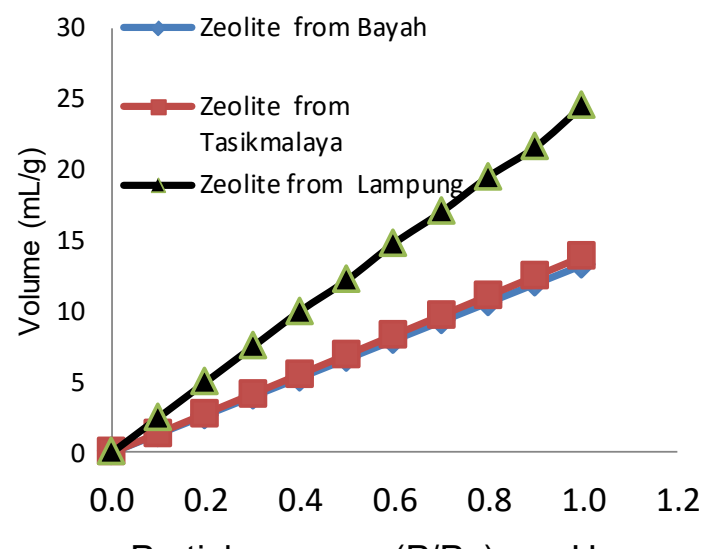

Partial pressure (P/Po), $\mathrm{mmHg}$

Fig. 2. Adsorption of zeolites from Bayah, Lampung, and Tasikmalaya.

$\left(10.048 \mathrm{~m}^{2}\right)$ than those from Tasikmalaya $\left(8.332 \mathrm{~m}^{2}\right)$ and Bayah $\left(6.353 \mathrm{~m}^{2}\right)$. For zeolites from Lampung, Tasikmalaya, and Bayah, the three types of zeolites each have the same pore size of $16.065,16.801$, and $16.235 \AA$, respectively.

Apart from the surface area and pore size analyses, adsorption analysis of each type of zeolite against $\mathrm{N}_{2}$ at room temperature under isothermal conditions can be used to draw a correlation between partial pressure $(\mathrm{P} / \mathrm{Po}, \mathrm{mmHg})$ and volume $(\mathrm{ml} / \mathrm{g})$, as shown in Fig. 2.

Figure 2 and Table 2 show that zeolite from Lampung had the highest adsorption capacity, i.e., $24.500 \mathrm{ml} / \mathrm{g}$, followed by zeolites from Tasikmalaya and Bayah at $13.800 \mathrm{ml} / \mathrm{g}$ and $13.250 \mathrm{ml} / \mathrm{g}$, respectively, at a partial pressure $(\mathrm{P} / \mathrm{Po})$ of $1 \mathrm{mmHg}$ [8]. Analyses of the surface area, specific pore size, and absorption of the three types of zeolite showed that the zeolite from Lampung was the most suitable as an absorbent of fission isotopes in nuclear fuel.

\section{Time optimization of the cation exchange process for ${ }^{137} \mathrm{Cs}$ isotope}

Table 3 shows the results of the optimization of the time taken for the cation exchange process from ${ }^{137} \mathrm{Cs}$ isotope to $\mathrm{NH}_{4}^{+}$-zeolite (that's from Bayah, Lampung, and Tasikmalaya) that was stirred for 1 , $2,3,4,5$, and $24 \mathrm{~h}$ [19].

Table 3 shows that the optimization of the Cs ion exchange process by $\mathrm{NH}_{4}$-zeolite occurred at a stirring time of $1 \mathrm{~h}$. The process of Cs ion exchange by zeolite from Lampung is greater when compared to zeolites from Bayah and Tasikmalaya. The decrease in the milli-equivalent value of Cs ions which can
Table 3. Optimization time of the ${ }^{137} \mathrm{Cs}$ cation exchange process with $\mathrm{NH}_{4}$-zeolites

\begin{tabular}{cccc}
\hline $\begin{array}{c}\text { Stirring } \\
\text { time } \\
(\mathrm{h})\end{array}$ & $\begin{array}{c}\text { Zeolites } \\
\text { from Bayah } \\
(\mathrm{mEq} / \mathrm{g})\end{array}$ & $\begin{array}{c}\text { Zeolites from } \\
\text { Lampung } \\
(\mathrm{mEq} / \mathrm{g})\end{array}$ & $\begin{array}{c}\text { Zeolites from } \\
\text { Tasikmalaya } \\
(\mathrm{mEq} / \mathrm{g})\end{array}$ \\
\hline 0 & 0.00 & 0.00 & 0.00 \\
1 & 1.46 & 1.57 & 1.41 \\
2 & 1.40 & 1.45 & 1.40 \\
3 & 1.38 & 1.44 & 1.40 \\
4 & 1.35 & 1.46 & 1.39 \\
5 & 1.34 & 1.45 & 1.38 \\
24 & 1.34 & 1.44 & 1.38 \\
\hline
\end{tabular}

be exchanged with $\mathrm{NH}_{4}$-zeolite occurs very significantly at stirring for up to $1 \mathrm{~h}$, both for zeolites from Bayah, Lampung, and Tasikmalaya. At the contact times greater than $1 \mathrm{~h}$, i.e., $(2,3,4,5$, and $24 \mathrm{~h})$, there was a decrease in the value of milli-equivalent of Cs ions exchanged by $\mathrm{NH}_{4}^{+}$-zeolites from each of the three regions.

When the stirring time is more than $1 \mathrm{~h}$, there is a decrease in the exchange of Cs ions by zeolites. Increased stirring time up to $24 \mathrm{~h}$ causes the temperature of the solution to increase. This phenomenon becomes a barrier or disturbance to the strength of the Cs ion bonding, especially for the absorption process, so that the Cs ions are easily separated from the zeolite structure. The cation exchange process occurs at $84.54 \%$, while the absorption process is only $15.46 \%$, as explained in the next section. The decrease in absorption of Cs ions by zeolites from Bayah and the process is very comparable to the decrease obtained for zeolites from Lampung and Tasikmaya.

The effective CEC of Cs with $\mathrm{NH}_{4}^{+}$-zeolite was determined by stirring for $1 \mathrm{~h}$. The CEC of zeolite from Lampung was $1.448 \mathrm{mEq} / \mathrm{g}$, which was larger than that of the zeolites from Bayah and Tasikmalaya, which had CEC values of 1.427 and $1.404 \mathrm{mEq} / \mathrm{g}$ with standard deviation (SD) and relative standard deviation (RSD), respectively as shown in Table 4. The CEC values of zeolites from Bayah, Lampung, and Tasikmalaya did not have significant differences when compared with the CEC values obtained by other researchers $[5,20]$.

The diffusion coefficient $\left(D_{i}\right)$ of zeolites from Bayah, Lampung, and Tasikmalaya was determined in a manner similar to how CEC was measured. The

Table 4. Analysis of cation exchange capacity (CEC)

\begin{tabular}{lcccc}
\hline $\begin{array}{c}\text { Origin } \\
\text { of zeolite }\end{array}$ & $\begin{array}{c}\mathrm{CEC} \\
(\mathrm{mEq} / \mathrm{g})\end{array}$ & $\begin{array}{c}\text { CEC } \\
\text { average } \\
(\mathrm{mEq} / \mathrm{g})\end{array}$ & $\begin{array}{c}\mathrm{SD} \\
(\mathrm{mEq} / \mathrm{g})\end{array}$ & $\begin{array}{c}\mathrm{RSD} \\
(\%)\end{array}$ \\
\hline Bayah & 1.460 & & & \\
& 1.438 & 1.427 & 0.040 & 2.79 \\
& 1.383 & & & \\
Lampung & 1.454 & & & \\
& 1.454 & 1.448 & 0.010 & 0.71 \\
& 1.436 & & & \\
Tasikmalaya & 1.409 & & & \\
& 1.404 & 1.404 & 0.005 & 0.36 \\
& 1.399 & & & \\
\hline
\end{tabular}


Table 5. Weight fractions $\left(F_{t} / F_{\sim}\right.$ at $\left.30^{\circ} \mathrm{C}\right)$ of Cs ion at various stirring times

\begin{tabular}{cccc}
\hline \multirow{2}{*}{$\begin{array}{c}\text { Time } \\
(\mathrm{h})\end{array}$} & \multicolumn{3}{c}{ Weight fractions of Cs ions at $30^{\circ} \mathrm{C}$} \\
\cline { 3 - 4 } & Bayah & Lampung & Tasikmalaya \\
\hline 0 & 0.00 & 0.00 & 0.00 \\
1 & 1.09 & 1.09 & 0.99 \\
2 & 1.01 & 1.04 & 0.99 \\
3 & 1.00 & 1.03 & 0.98 \\
4 & 1.01 & 1.01 & 0.99 \\
5 & 1.00 & 1.01 & 0.98 \\
24 & 1.00 & 1.00 & 1.00 \\
\hline
\end{tabular}

Table 6. Weight fractions $\left(F_{t} / F_{\sim}\right.$ at $\left.50^{\circ} \mathrm{C}\right)$ of Cs ion at various stirring times

\begin{tabular}{cccc}
\hline \multirow{2}{*}{$\begin{array}{c}\text { Time } \\
(\mathrm{h})\end{array}$} & \multicolumn{3}{c}{ Weight fractions of Cs ions at $50^{\circ} \mathrm{C}$} \\
\cline { 3 - 4 } & Bayah & Lampung & Tasikmalaya \\
\hline 0 & 0.00 & 0.00 & 0.00 \\
1 & 0.98 & 0.99 & 0.97 \\
2 & 0.95 & 0.97 & 0.94 \\
3 & 0.96 & 0.97 & 0.95 \\
4 & 0.96 & 0.97 & 0.96 \\
5 & 0.96 & 0.97 & 0.97 \\
24 & 1.00 & 1.00 & 1.00 \\
\hline
\end{tabular}

Table 7. Diffusion coefficient at $30^{\circ} \mathrm{C}$ and $50^{\circ} \mathrm{C}$

\begin{tabular}{lccc}
\hline \multirow{2}{*}{$\begin{array}{c}\text { Temperature } \\
\left({ }^{\circ} \mathrm{C}\right)\end{array}$} & \multicolumn{3}{c}{ Diffusion coefficient $\left(D_{i}\right)\left(\mathrm{m}^{2} / \mathrm{s}\right)$} \\
\cline { 2 - 4 } & Bayah & Lampung & Tasikmalaya \\
\hline 30 & $2.30 \mathrm{E}-13$ & $2.35 \mathrm{E}-13$ & $2.06 \mathrm{E}-13$ \\
50 & $9.34 \mathrm{E}-14$ & $9.62 \mathrm{E}-14$ & $9.62 \mathrm{E}-14$ \\
\hline
\end{tabular}

ion exchange process was conducted using contact durations of $1,2,3,4,5$, and $24 \mathrm{~h}$ at temperatures of $30^{\circ} \mathrm{C}$ and $50^{\circ} \mathrm{C}$. The weight fractions of the Cs ions $\left(F_{t} / F_{\sim}\right)$ variables with contact durations during the ion exchange process and the rate of Cs sorption into the zeolite are listed in Tables 5 and 6.

This suggested that the diffusion process probably occurred fastest within $1 \mathrm{~h} . D_{i}$ values were obtained from the slope of $F_{t} / F$ versus $v_{t}$ shown in Fig. 3 for a temperature of $30^{\circ} \mathrm{C}$ and Fig. 4 for a temperature of $50^{\circ} \mathrm{C}$.

Figures 3 and 4 show that the zeolite from Lampung had a higher sorption rate than those from Bayah and Tasikmalaya, but the difference was not very large. The $D_{i}$ values for the three types of natural zeolite at temperatures of $30^{\circ} \mathrm{C}$ and $50^{\circ} \mathrm{C}$ are listed in Table 7 .

The $D_{i}$ values of these three zeolites were almost identical. This was probably because the compositions of these natural zeolites were also almost the same, as indicated by the XRF analysis of their chemical compositions (Table 1). The $E_{a}$ value was determined by calculating the relationship between Ln $D_{i}$ and 1/T using Eq. (2). This yielded $E_{a}$ values of $36.61,36.61$, and $31.09 \mathrm{~kJ} / \mathrm{mole}$ for the zeolites from Bayah, Lampung, and Tasikmalaya, respectively. These $E_{a}$ values were greater than that of the standard zeolite (mordenite), which has an $E_{a}$ value of $9.06 \mathrm{~kJ} / \mathrm{mole}$. This is because the natural zeolites have complex compositions that made it possible for them to contain more than one type of crystal structure. Therefore, it could be concluded that the

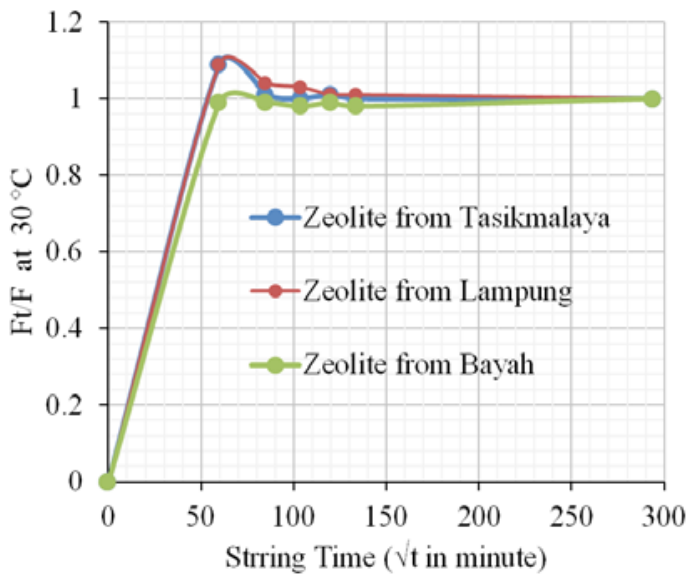

Fig. 3. Relationship between the fraction values of zeolite ions exchanged at time $t$ for a temperature of $30^{\circ} \mathrm{C}$.

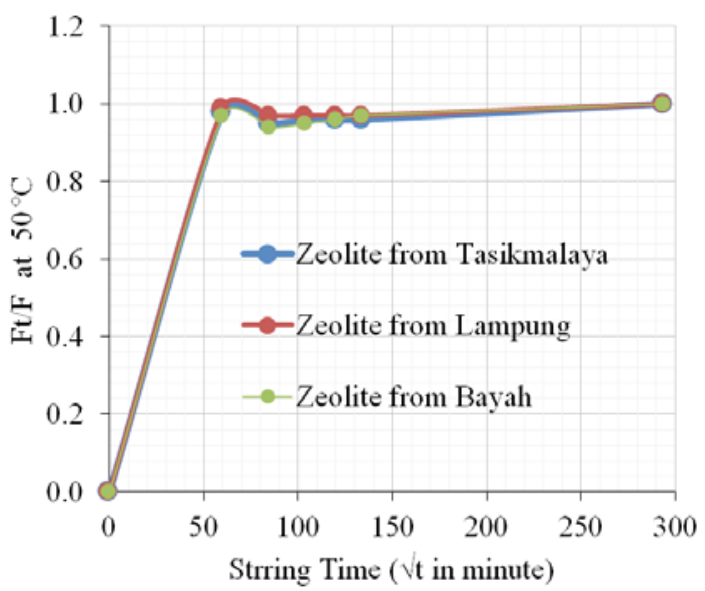

Fig. 4. Relationship between the fraction values of zeolite ions exchanged at time $t$ for a temperature of $50^{\circ} \mathrm{C}$.

Cs cation exchange in the natural zeolite was more difficult than that in the synthesized zeolite.

The results of the characterization showed that zeolite from Lampung had better character compared to zeolites from Bayah and Tasikmalaya, so zeolite from Lampung was used as cation exchanged for the separation of ${ }^{137} \mathrm{Cs}$ in nuclear fuel.

\section{Heat treatment of stable ${ }^{137} \mathrm{Cs}$-zeolite bonds}

The stability of the ${ }^{137} \mathrm{Cs}$-zeolite bond was tested heat treatment in $25,200,500$, and $600^{\circ} \mathrm{C}$. The results showed that there was no significant release of ${ }^{137} \mathrm{Cs}$ isotopes from the structure of the zeolite. Heat treatment up to $600^{\circ} \mathrm{C}$ allowed the ${ }^{137} \mathrm{Cs}$ isotope to become separated from the structure of the zeolite, after which a leaching test was performed on the ${ }^{137} \mathrm{Cs}$-zeolite solids in the water to determine the effect of the heat treatment on the absorption of ${ }^{137} \mathrm{Cs}$ by the zeolites. Upon heating to $600^{\circ} \mathrm{C},{ }^{137} \mathrm{Cs}$ isotopes did not leach into the water. When the leaching did occur, the cation exchange and adsorption processes were at $84.54 \%$ and approximately $15.46 \%$, respectively, as shown in Table 8.

However, Table 8 shows that the separation of ${ }^{137} \mathrm{Cs}$ isotope from zeolite did not enable the leaching process to occur in order not to disturb the ${ }^{137} \mathrm{Cs}$ 
Table 8. Results of leaching ${ }^{137}$ Cs-zeolite from Lampung

\begin{tabular}{lcccc}
\hline \multirow{2}{*}{$\begin{array}{c}\text { Heating temperature } \\
\left({ }^{\circ} \mathrm{C}\right)\end{array}$} & $\begin{array}{c}\mathrm{Cs} \\
(\mathrm{mEq} / 10 \mathrm{ml})\end{array}$ & $\begin{array}{c}\text { Cs } \\
(\mathrm{mEq} / \mathrm{g} \text { zeolite })\end{array}$ & Leachates $(\%)$ & Zeolite $(\%)$ \\
\hline 25 (no heating) & 0.221 & 0.0221 & 15.46 & 84.54 \\
200 & 0.004 & 0.0004 & 0.27 & 99.73 \\
500 & 0.001 & 0.0011 & 0.06 & 99.94 \\
600 & 0.001 & 0.0011 & 0.06 & 99.94 \\
\hline
\end{tabular}

Table 9. Fission products and half-life of isotopes

\begin{tabular}{lcc}
\hline \multicolumn{1}{c}{ Isotopes } & Fission yield $(\%)$ & Half-life \\
\hline${ }^{134} \mathrm{Cs}$ & 6.80 & 2.10 years \\
${ }^{137} \mathrm{Cs}$ & 6.20 & 30.17 years \\
${ }^{90} \mathrm{Sr}$ & 5.93 & 29 years \\
${ }^{140} \mathrm{Ba}$ & 6.36 & 12.8 days \\
${ }^{144} \mathrm{Ce}$ & 4.50 & 285 days \\
\hline
\end{tabular}

Table 10. Selectivity coefficient of zeolites from Lampung [21]

\begin{tabular}{lcccc}
\hline $\begin{array}{c}\text { Cation } \\
\text { exchange }\end{array}$ & $\mathrm{Cs}^{+}$ & $\mathrm{Sr}^{2+}$ & $\mathrm{Ba}^{2+}$ & $\mathrm{Ce}^{+}$ \\
\hline $\mathrm{NH}_{4}$-zeolite & 1.44 & 1.22 & 1.22 & 1.10 \\
K-zeolite & 1.20 & 1.04 & 1.10 & 1.00 \\
Na-zeolite & 1.40 & 1.04 & 1.12 & 1.00 \\
\hline
\end{tabular}

isotope because the ${ }^{137} \mathrm{Cs}$ isotope bonding by the zeolite reached $84.54 \%$. When the heating at $200^{\circ} \mathrm{C}$ was followed by the leaching process, a $99.73 \%$ fraction yield of ${ }^{137}$ Cs isotope in the zeolite was obtained. This indicated that the heating process allowed the ${ }^{137} \mathrm{Cs}$ isotope to be bound to the inner structure of zeolite, but also that the ability of the zeolite to bind ${ }^{137} \mathrm{Cs}$ did not increase as the temperature increased.

\section{The effectiveness of $\mathrm{NH}_{4}$-zeolite with $\mathrm{Cs}, \mathrm{Sr}, \mathrm{Ba}$ and $\mathrm{Ce}$ ions}

Nuclear fuel of post-irradiation contains isotopes of fission products as gamma radiation transmitters such as ${ }^{134} \mathrm{Cs},{ }^{137} \mathrm{Cs},{ }^{90} \mathrm{Sr},{ }^{140} \mathrm{Ba}$, and ${ }^{144} \mathrm{Ce}$. The amount of isotopes in nuclear fuel varies depending on the fission yield and half-life, as shown in Table 9.

Competition between isotopes can occur when the ${ }^{137} \mathrm{Cs}$ isotope is separated from other isotopes using zeolite from Lampung. Therefore, it is necessary to test the selectivity of $\mathrm{NH}_{4}$-zeolite cation with $\mathrm{Cs}, \mathrm{Sr}, \mathrm{Ba}$, and $\mathrm{Ce}$ [21]. The selectivity test results of the $\mathrm{NH}_{4}$-zeolite cation with $\mathrm{Cs}$, Sr, Ba, and $\mathrm{Ce}$ are shown in Fig. 5.

Figure 5 shows that ${ }^{137} \mathrm{Cs}$ isotope is more selective toward $\mathrm{NH}_{4}$-zeolite compared to ${ }^{90} \mathrm{Sr},{ }^{144} \mathrm{Ba}$, and ${ }^{144} \mathrm{Ce}$ isotopes. This is because the size of the $\mathrm{NH}_{4}$ ion radius is $148 \mathrm{pm}$, while the size of the $\mathrm{Cs}^{+}$and $\mathrm{Sr}^{2+}$ ions is $167 \mathrm{pm}$ and $112 \mathrm{pm}$, but the hydrated radii of $\mathrm{NH}_{4}, \mathrm{Cs}^{+}$, and $\mathrm{Sr}^{2+}$ are 331, 329 and $412 \mathrm{pm}$, so $\mathrm{Cs}^{+}$will be easier to exchange with $\mathrm{NH}_{4}$ compared to $\mathrm{Sr}^{2+}$ in the zeolite framework. This is supported by the results of other researchers regarding the calculation of the selectivity coefficient of zeolites from Lampung for the $\mathrm{Cs}^{+}, \mathrm{Sr}^{2+}, \mathrm{Ba}$, and $\mathrm{Ce}$ ions as shown in Table 10 [21].

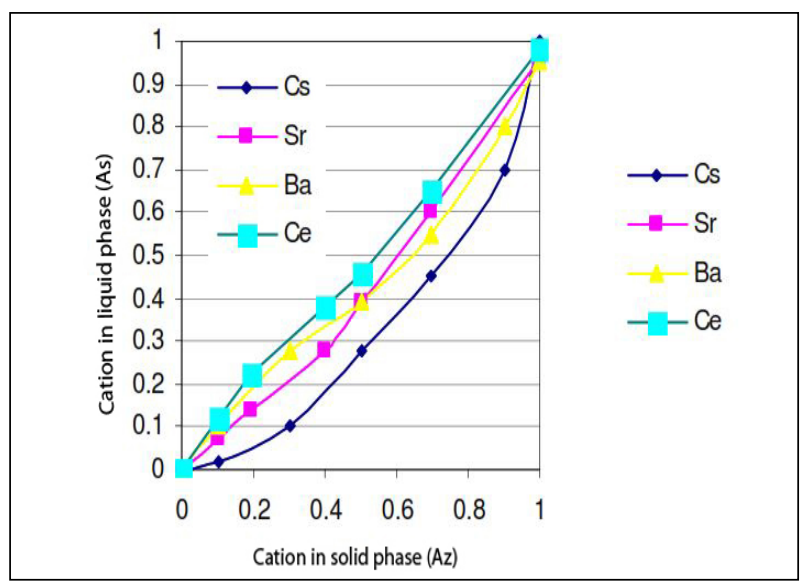

Fig. 5. The selectivity test results of $\mathrm{NH}_{4}$-zeolite with Cs, $\mathrm{Sr}, \mathrm{Ba}$, and $\mathrm{Ce}$ ions.

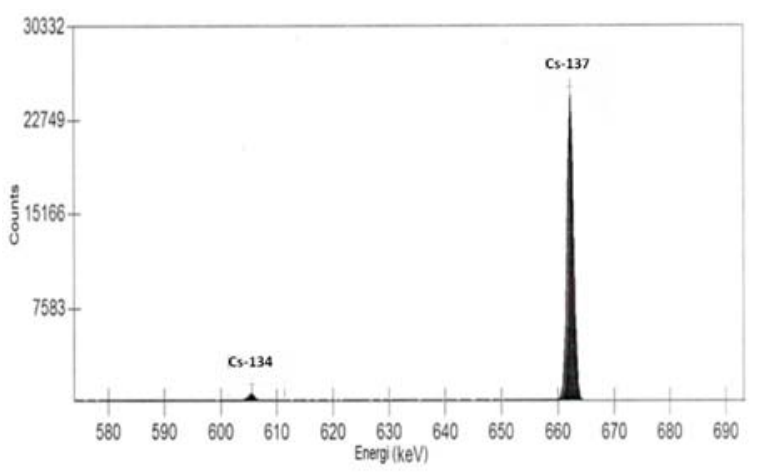

Fig. 6. The spectrum isotope of ${ }^{134} \mathrm{Cs}$ and ${ }^{137} \mathrm{Cs}$.

\section{Separation of the ${ }^{137}$ Cs using zeolites from Lampung} and compared with Dowex resin

The results of the separation of ${ }^{137} \mathrm{Cs}$ isotope in nuclear fuel of $\mathrm{U}_{3} \mathrm{Si}_{2} / \mathrm{Al}$ post-irradiation by a cation exchange method using zeolites from Lampung are shown in Fig. 6 and Table 11, while the separation of ${ }^{137}$ Cs using Dowex resin (synthetic resin) is shown in Table 12.

Figure 6 shows the isotopes spectrum of ${ }^{134} \mathrm{Cs}$ and ${ }^{137} \mathrm{Cs}$ bound in the solid phase at $604.7 \mathrm{keV}$ and $661.7 \mathrm{keV}$, respectively. The isotope content of ${ }^{134} \mathrm{Cs}$ obtained by measuring cesium using a gamma spectrometer is very small while the content of ${ }^{137} \mathrm{Cs}$ is very large. This is due to a half-life of ${ }^{134} \mathrm{Cs}$ of only around 2.1 years and ${ }^{137} \mathrm{Cs}$ of around 30.17 years.

From Tables 11 and 12 obtained recovery separations for ${ }^{137} \mathrm{Cs}$ isotope in $\mathrm{U}_{3} \mathrm{Si}_{2} / \mathrm{Al}$ fuel post-irradiation using zeolite from Lampung and resin Dowex was about the same around 98\% to 99\%. This shows that zeolite Lampung can replace resin Dowex as a cation exchange material for the separation of ${ }^{137} \mathrm{Cs}$ isotope. 
Table 11. Recovery of ${ }^{137} \mathrm{Cs}$ isotope in the fuel element plate of $\mathrm{U}_{3} \mathrm{Si}_{2} / \mathrm{Al}$ using zeolite

\begin{tabular}{lcccc}
\hline Sample code & $\begin{array}{c}\text { Weight of sample } \\
\text { in 150 mL } \\
\text { (g solution) }\end{array}$ & $\begin{array}{c}\text { Content of }{ }^{137} \mathrm{Cs} \\
\text { before given zeolite } \\
(\mathrm{mg})\end{array}$ & $\begin{array}{c}\text { Content of }{ }^{137} \mathrm{Cs} \\
\text { after given zeolite } \\
(\mathrm{mg})\end{array}$ & $\begin{array}{c}\text { Recovery } \\
(\%)\end{array}$ \\
\hline Top & 0.1539 & 0.0287 & 0.0285 & 99.3031 \\
Middle & 0.1546 & 0.0343 & 0.0340 & 99.1253 \\
Bottom & 0.1557 & 0.0447 & 0.0443 & 99.1051 \\
\hline
\end{tabular}

Table 12. Recovery of ${ }^{137} \mathrm{Cs}$ isotope in the fuel element plate of $\mathrm{U}_{3} \mathrm{Si}_{2} / \mathrm{Al}$ using resin Dowex

\begin{tabular}{lcccc}
\hline Sample code & $\begin{array}{c}\text { Weight of sample } \\
\text { in } 150 \mathrm{~mL} \\
\text { (g solution) }\end{array}$ & $\begin{array}{c}\text { Content of }{ }^{137} \mathrm{Cs} \\
\text { before given zeolite } \\
(\mathrm{mg})\end{array}$ & $\begin{array}{c}\text { Content of }{ }^{137} \mathrm{Cs} \\
\text { after given zeolite } \\
(\mathrm{mg})\end{array}$ & $\begin{array}{c}\text { Recovery } \\
(\%)\end{array}$ \\
\hline Top & 0.1554 & 0.0341 & 0.0334 & 98.0122 \\
Middle & 0.1542 & 0.0302 & 0.0297 & 98.4482 \\
Bottom & 0.1540 & 0.0284 & 0.0276 & 98.1428 \\
\hline
\end{tabular}

\section{Conclusion}

Zeolites from Lampung had the greatest $\mathrm{Si} / \mathrm{Al}$ ratio, CECs, surface area, and adsorption when compared to those from Bayah and Tasikmalaya. The $D_{i}$ of Cs ions into the zeolite from Bayah, Lampung, and Tasikmalaya had almost the same values: $2.3 \times 10^{-13.13} \mathrm{~m}^{2} / \mathrm{s}, 2.3 \times 10^{-13.13} \mathrm{~m}^{2} / \mathrm{s}$, and $2.1 \times 10^{-13}$ $\mathrm{m}^{2} / \mathrm{s}$, respectively, at $30^{\circ} \mathrm{C}$ and $9.3 \times 10^{-14.13} \mathrm{~m}^{2} / \mathrm{s}$, $9.6 \times 10^{-14.13} \mathrm{~m}^{2} / \mathrm{s}$, and $9.6 \times 10^{-14} \mathrm{~m}^{2} / \mathrm{s}$ at $50^{\circ} \mathrm{C}$. The results calculating the kinetic reaction parameters of the ion exchanges as the activation energy $\left(E_{a}\right)$ of the three types of zeolites were also similar: i.e., they were $36.61,36.61$, and $31.09 \mathrm{~kJ} / \mathrm{mole}$ for the zeolites from Bayah, Lampung, and Tasikmalaya, respectively. Furthermore, the stability of the ${ }^{137} \mathrm{Cs}$-zeolite bond under heat treatment showed that the release of ${ }^{137} \mathrm{Cs}$ ions occurred irrespective of the structure of the zeolite; therefore, it did not need the leaching process that did not occur with Cs desorption. Thus, based on the characteristics of the three zeolites, the zeolite from Lampung was determined to be the most suitable for use as a cation exchange material for ${ }^{137} \mathrm{Cs}$ isotope in post-irradiated fuel.

The results of the recovery separation of ${ }^{137} \mathrm{Cs}$ isotope in nuclear fuel of $\mathrm{U}_{3} \mathrm{Si}_{2} / \mathrm{Al}$ post-irradiated using zeolite from Lampung and resin Dowex were about the same around 98-99\%. This shows that zeolite Lampung can replace resin Dowex as a cation exchange material for the separation of ${ }^{137} \mathrm{Cs}$ isotope in nuclear fuel.

Acknowledgment. I would like to thank my friends Dian Anggraini, Ariyanti Saputri, and the physicochemical team that assisted me in the implementation of this research.

\section{ORCID}

A. Br. Ginting (D http://orcid.org/0000-0002-9464-4880

\section{References}

1. ASTM. (2014). Standard practice for the ion exchange separation of uranium and plutonium prior to isotopic analysis. (ASTM C-1411).

2. Wiyantoko, B., \& Rahman, N. (2017). Measurement of cation exchange capacity (CEC) on natural zeolite by percolation method. AIP Conf. Proc., 1911, 020021. https://doi.org/10.1063/1.5016014.

3. Ilić, B., \& Wettstein, S. (2017). A review of adsorbate and temperature-induced zeolite framework flexibility. Microporous Mesoporous Mat., 239, 221-234. https://doi.org/10.1016/j.micromeso. 2016.10.005.

4. Kong, M., Liu, Z., Vogt, T., \& Lee, Y. (2016). Chabazite structures with $\mathrm{Li}, \mathrm{Na}, \mathrm{Ag}, \mathrm{K}, \mathrm{NH}_{4}, \mathrm{Rb}$ and $\mathrm{Cs}$ as extra-framework cations. Microporous Mesoporous Mat., 221, 253-263. https://doi.org/10.1016/j. micromeso. 2015.09.031.

5. Sing, D. N., \& Kolay, P. K. (2002). Simulation of ash-water interaction and its influence on ash characteristics. Prog. Energy Cumbust. Sci., 28, 267-299.

6. Dyer, A., Harjula, R., Newton, J., \& Pilinger, M. (2010). Synthesis and characterisation of mesoporous silica phases containing heteroatoms, and their cation exchange properties. Part 5: Cation exchange isotherms, and the measurement of radioisotope distribution coefficients, for an MCM-22 phase containing aluminium. Microporous Mesoporous Mat., 135(1/3), 21-29. https://doi.org/10.1016/j.micromeso. 2010.06.006.

7. Pepe, F., de Gennaro, B., Aprea, P., \& Caputo, D. (2013). Natural zeolites for heavy metals removal from aqueous solutions: Modeling of the fixed bed $\mathrm{Ba}^{2+} / \mathrm{Na}^{+}$ion-exchange process using a mixed phillipsite/chabazite-rich tuff. J. Chem. Eng., 219, 37-42. https://doi.org/10.1016/j.cej.2012.12.075.

8. Ginting, A. Br., \& Anggraini, D. (2012). The effect of zeolite addition on the of ${ }^{137} \mathrm{Cs}$ in irradiated $\mathrm{U}_{3} \mathrm{Si}_{2}-\mathrm{Al}$ fuel element plate. Journal Teknol. Bahan Nuklir, $7(2), 123-135$.

9. Wang, S., \& Peng, Y. (2010). Natural zeolites as effective adsorbents in water and wastewater treatment. Chem. Eng. J., 156, 11-24. https://doi.org/10.1016/j. cej.2009.10.029.

10. Estiaty, L. M. (2010). Engineering of zeolite mineral with wet impregnation inhibitor metal method as raw 
material of antiseptic by continous flow method. Jurnal Zeolit Indonesia, 9(2), 6-70. (in Indonesian).

11. Johan, E., Yamada, T., Wazingwa Munthali, M., Kabwadza-Corner, P., Aono, H., \& Matsue, N. (2015). Natural zeolites as potential materials for decontamination of radioactive cesium. Procedia Environ. Sci., 28, 52-56.

12. Zhang, J., Singh, R., \& Webley, P. A. (2008). Alkali and alkaline-earth cation exchanged chabazite zeolites for adsorption based $\mathrm{CO}_{2}$ capture. Microporous Mesoporous Mat., 111(1/3), 478-487. DOI:10.1016/j. micromeso.2007.08.022.

13. Borai, E. H., Harjula, R., Malinen, L., \& Paajanen, A. (2009). Efficient removal of cesium from low-level radioactive liquid waste using natural and impregnated zeolite minerals. J. Hazard. Mater., 172 (1), 416-422. https://doi.org/10.1016/j.jhazmat. 2009.07.033.

14. Vipin, A. K., Ling, S., \& Fugetsu, B. (2016). Removal of $\mathrm{Cs}^{+}$and $\mathrm{Sr}^{2+}$ from water using MWCNT reinforced Zeolite-A beads. Microporous Mesoporous Mat., 224, 84-88. https://doi.org/10.1016/j.micromeso. 2015.11.024.

15. Cortés-Martínez, R., Olguín, M. T., \& Solache-Ríos, M. (2010). Cesium sorption by clinoptilolite-rich tuffs in batch and fixed-bed systems. Desalination, 258(1/3), 164-170. https://doi.org/10.1016/j.desal.2010.03.019.
16. El-Kamash, A. M. (2008). Evaluation of zeolite for the sorptive removal of $\mathrm{Cs}^{+}$and $\mathrm{Sr}^{2+}$ ions from aqueous solutions using batch and fixed bed column operations. J. Hazard. Mater., 151(2/3), 432-445. https:// doi.org/10.1016/j.jhazmat.2007.06.009.

17. Chegrouche, S., Mellah, A., \& Barkat, M. (2009). Removal of strontium from aqueous solutions by adsorption onto activated carbon: kinetic and thermodynamic studies. Desalination, 235(1/3), 306-318. DOI:10.1016/j.desal.2008.01.018.

18. Abdel Moamen, O. A., Ismail, I. M., Abdelmonem, N., \& Abdel Rahman, R. O. (2015). Factorial design analysis for optimizing the removal of cesium and strontium ions on synthetic nano-sized zeolite. Journal Taiwan Inst. Chem. Eng., 55, 133-144. https:// doi.org/10.1016/j.jtice.2015.04.007.

19. Inglezakis, V. J. (2005). The concept of "capacity" in zeolite ion-exchange systems. J. Colloid Interface Sci., 281, 68-79. DOI:10.1016/j.jcis.2004.08.082.

20. Sukor, A., Azira, A. Z. A., \& Husni, M. H. A. (2017). Determination of cation exchange capacity of natural zeolite: A revisit. Malaysian Journal of Soil Science, 21, 105-112. http://www.msss.com.my/.

21. Siti, A., Anggraini, D., Nampira, Y., Rosika, R., Noviarti, N., \& Nugroho, A. (2003). Selectivity of Lampung zeolite towards matrices cations generated from uranium fission. Jurnal Zeolit Indonesia, 2(1), 9-14. (in Indonesian). 